\title{
The Reception of Anglo-American Drama \\ During the Great War in Period Newspapers
}

\author{
[Recepce angloamerickeho repertoaru \\ v dobe prvni svetové valky v dobovem regionalním tisku]
}

\author{
Ivona Misterova
}

\section{DOI: 10.18355/XL.2015.08.01.88-100}

\begin{abstract}
Abstrakt
Během první světové války se divadlo stalo účinným komunikačním kanálem a prostředkem povzbuzení. V době ekonomických nesnází a politické paralýzy napomáhala divadelní představení k rozvoji českého národního uvědomění a stimulaci národní identity. Činoherní repertoár byl orientován především na národní klasiky (např. Klicpera, Tyl, Jirásek) a „demokratické“ drama (např. Shaw). Značný divadelní prostor byl vyhrazen shakespearovskému dramatu. Jeden z největších divadelních počinů $\mathrm{v}$ tomto ohledu představoval shakespearovský festival, který se uskutečnil na jaře roku 1916 v Národním divadle Praze a mnoha dalších českých divadlech. Osobitého rázu nabyl díky Jaroslavu Počepickému a Bedřichu Karenovi také v Plzni. Shakespearovský dramatický cyklus měl nejen umělecký, ale přirozeně také politický dopad. Shakespeare se stal, obrazně řečeno, inspirátorem a spolutvůrcem národní historie.

Cílem studie je prokázat, jaký prostor zaujímalo anglické a americké drama v celkové skladbě činoherního repertoáru $\mathrm{v}$ době první světové války v Městském divadle $\mathrm{v}$ Plzni a v chronologické perspektivě vysledovat recepci jednotlivých nastudování, např. Kupce benátského, Kapitána Brassbounda, Bouře, Androkla a lva, Hamleta, Zachránění Benátek aj., v dobovém periodickém tisku, zejména v listech Český deník a Nová doba.

Klíčová slova

William Shakespeare, první světová válka, České země, Plzeň, Městské divadlo v Plzni, Shakespearovský festival
\end{abstract}

\section{Plzeň v době první světové války}

Atentát na následníka trůnu Františka Ferdinanda d'Este dne 28. června 1914 rozpoutal mašinerii první světové války, jež zachvátila téměř celou Evropu. Válečné události postihly netušenou měrou také zázemí, které se potýkalo $\mathrm{s}$ nedostatkem potravin, paliva a nemocemi. Vzhledem $\mathrm{k}$ tomu, že Plzeň nebyla válečným konfliktem bezprostředně ohrožena, reagovali občané na vyhlášení války zpočátku s jistým odstupem a snad i zvědavostí. Loajální stanovisko vůči vládě zaujala sociální demokracie, třebaže se původně k hrozícímu střetu na Balkáně stavěla odmítavě. Se sílícími hospodářskými problémy se však postoj Plzeňanů začal proměňovat. Škodovka ${ }^{1}$ a další plzeňské závody zajišt'ující válečnou produkci zaměstnávaly tisíce nově rekrutovaných dělníků, pro něž však nebyla zajištěna potřebná infrastruktura (Martinovsky a kol., 2004: 181). Zatímco zbrojní výroba prosperovala, zásobování potravinami i uhlím zaostávalo. Tíživá hospodářská situace

\footnotetext{
${ }^{1}$ Výnosem Ministerstva vnitra se ve druhé polovině roku 1914 Škodovy závody ocitly pod př́mým vojenským dohledem. Pracovníci skládali vojenskou přísahu, podléhali vojenské kázni a vojenským zákonům.
} 
vyvrcholila vlnou protestních stávek a demonstrací. V roce 1916 a znovu o dva roky později se ve městě rozpoutaly hladové bouře, jejichž potlačení mělo tragické následky. V červnu 1918, kdy byl pro nedostatek mouky zastaven výdej chleba, padlo za obět' i několik dětí. Tragickou událostí byl rovněž výbuch muniční továrny v PlzniBolevci v květnu roku 1917, při němž zahynulo téměř 200 osob. ${ }^{1}$ Exploze bolevecké továrny se stala předobrazem katastrofického výbuchu v Čapkově románu Krakatit. Čapek, který v té době působil jako vychovatel v rodině hraběte Vladimíra Lažanského na zámku Chyše, uslyšel vzdálenou detonaci a spatřil hustý černý dým stoupající z požáru, a stal se de facto očitým svědkem katastrofy (Martinovsky a kol., 2004: 184). Svoji daň si vyžádala i epidemie španělské chřipky, která se v Plzni rozšíríila v polovině záŕí 1918. Onemocněla jí téměř třetina obyvatel.

Tíživá společenská, ekonomická i politická situace sjednotila politické strany v negativním náhledu na možnost perspektivního vývoje v rámci RakouskaUherska a podnítila ideu obnovení autonomie českého národa. Vstupem Spojených států do války v roce 1917 došlo k zásadnímu obratu. Následující události se již nesly v duchu končící války, jejíž výsledek předznamenala čtrnáctibodová vize amerického prezidenta Thomase Woodrowa Wilsona o demokratickém uspořádání poválečného světa. Zpráva o přijetí podmínek př́měří a kapitulaci Rakouska-Uherska, jež se $\mathrm{v}$ Plzni rozšíríla dne 28. října 1918 dopoledne, vyvolala nadšenou odezvu. Moci se postupně (tak jako $\mathrm{v}$ Praze a jiných městech) chopil Národní výbor, sestavený $\mathrm{z}$ reprezentantů různých politických stran. Nově vzniklý Československý stát se pod vedením Tomáše Garrigua Masaryka rychle konsolidoval a stal se vyspělou, demokratickou a kulturní zemí. Cestou progresivního vývoje se v tomto období vydala také Plzeň, jíž nová geopolitická mapa Československého státu přiřkla výhodnou komunikační polohu. Ve druhé dekádě dvacátého století byla definitivně stvrzena průmyslová orientace města, třebaže rozpad habsburské monarchie připravil Škodovy závody o významné odbytiště. Kulturním symbolem města se stalo divadlo.

\subsection{Plzeňská činohra v době první světové války}

V roce 1912 se novým ředitelem divadla stal zpěvák a operní režisér Karel Veverka, který usiloval zejména o rozvoj opery. ${ }^{2}$ Režijně se podílel na mnoha významných operních představeních, zasloužil se rovněž o první českou premiéru Wagnerovy opery Rienzi (1914). Prosazoval vysokou úroveň uměleckého ztvárnění, které dosahoval kvalitním obsazením. Angažoval mj. dirigenta Václava Talicha, dirigenta a skladatele Ludvíka Vítězslava Čelanského a dirigenta Jaroslava Vogla. Pravidelně zval k pohostinským vystoupením význačné hudební umělce. Personální vývoj prodělal za Veverkova vedení i činoherní soubor, který se rozrostl o významné herecké osobnosti, např. Jaroslava Vojtu (1913 - 1915), Františka Kováŕíka (pohostinsky 1915 - 1918) a Gustava Hilmara (1912 - 1915). Oproti výraznému rozvoji opery činohra spíše stagnovala. ${ }^{3}$ Přes prvotní snahu o umělecké experimenty

${ }^{1}$ Přesný počet obětí bohužel není znám. Během požáru byly zničeny i písemné dokumenty.

${ }^{2}$ Karel Veverka $(1871$ - 1945) vedl plzeňské divadlo v letech 1912 - 1919 a poté opět v období $1926-1930$.

${ }^{3}$ Kmenovými členy a členkami činoherního souboru byli, např. Richard Branald, Josef Brzek, Gustav Černý, Karel Hostaš, Bedřich Karen, Fráňa Kohout, Adolf Kreuzmann, Vojtěch Matýs, Rudolf Novák, Miloš Nový, Jaroslav Pulda, František Sofron, Bohuš Vilím, Václav Vydra, Marie Bečvářová, Otýlie Beníšková, Marie Branaldová, Terezie Brzková, Běla Engelbertová, Antonie Fišerová, Klára Kašparová, 
se pozvolna vrátila $\mathrm{k}$ budilovskému stylu. ${ }^{1} \mathrm{Na}$ pozadí inovativních divadelních proudů představovaných Kvapilem a Hilarem znamenalo toto neživotné epigonství výrazný krok zpět.

V prvních dnech války divadlo krátce přerušilo provoz. ${ }^{2}$ Přestože všichni členové uměleckého souboru obdrželi „osmidenní výpověd’ pro mimořádné válečné poměry“, divadlo obnovilo činnost 15 . srpna svépomocnou akcí propuštěných herců. Odpoledne byla sehrána inscenace Našich furianti̊, večer Smetanova Prodaná nevěsta (Kriz, 1927: 52). Iniciativu podpořila Společnost českého divadla v Plzni (dále jen Společnost) a v podstatě i Karel Veverka přenecháním budov Městského divadla a tzv. divadla $\mathrm{Na}$ Zámečku k dispozici hercům. Pravidelný provoz byl obnoven po intervenci Společnosti 16. ř́ijna 1914. Prvním představením byla zpěvohra Karla Hašlera a Emiliana Starého Skvělá partie.

V sezóně 1914/1915 bylo celkově uspořádáno 362 představení, z nichž 142 tvořila činohra. Skladbu repertoáru ovlivňoval především výbor Společnosti. Činoherní ansámbl byl sice „slabší, ale v umělecké hodnotě ještě stále zdatný“ (Kriz, 1927: 52). Odchod Miloše Nového a Bohuše Vilíma byl kompenzován angažováním Jaroslava Puldy a Emanuela Rabase. V důsledku tristní finanční bilance po první válečné sezóně zvažoval výbor Společnosti zrušení stálého divadla. Po mnoha jednáních rozhodl sice pro jeho zachování, avšak s výhradně činoherním repertoárem. Tlak veřejnosti posléze přiměl Společnost k přehodnocení jednostranné programové skladby a postupnému začlenění operních představení. V sezóně 1915/1916, zahájené 28. záŕí 1915 Šrámkovou veselohrou Léto a ukončené 31. července 1916 Shakespearovým Hamletem s hostujícím Eduardem Vojanem v hlavní roli, bylo celkově sehráno 222 představení, z nichž $85 \%$ (tj. 188) tvořila činohra. Operní produkce se začaly sporadicky prosazovat až ve druhé polovině sezóny. Vzhledem k jmenování Karla Veverky velitelem plzeňské vojenské nemocnice a setníkem dělostřelců byl ve druhé válečné sezóně místoředitelem divadla ustaven Pravoslav Řada, člen Národního divadla v Praze ve výslužbě. Sezóna 1916/1917 byla již od počátku příznačná diváckou konjunkturou, vyznačující se těsnějším sepětím mezi umělci a publikem. „Ukázalo se $\mathrm{k}$ všeobecnému údivu, že dlouhotrvající válka a rostoucí drahota všech poživatin působí příznivě na návštěvu divadla.“ (Kriz, 1927:

Anuše Machová a Ludmila Sudová. Vrchním režisérem činohry byl na počátku války Miloš Nový, dramaturgem Pavel Nebeský. Na režijní práci se podíleli také Jaroslav Pulda a Richard Branald.

${ }^{1}$ Vendelín Budil (1847 - 1928) stál v čele plzeňského divadla v letech 1902 - 1912. Budilova režijní činnost se opírala o dobrou znalost národní i světové dramatické tvorby a značnou divadelní erudici. Herecky a režijně byl Budil následovníkem dvou významných divadelních osobností, Pavla Švandy ze Semčic a Josefa Jiřího Kolára. S Kolárem jej sbližovalo romantické pojetí uměleckého projevu a zájem o vypjatě dramatické a individualistické postavy, jejichž interpretaci Budil přiblížil reálnému životu. Budilova herecká a režijní koncepce byla ovlivněna rovněž školou Ermeta Zacconiho (1857 - 1948), jehož hereckému pojetí a režii dominoval naturalismus a verismus. Budilův osobitý herecký a režijní postoj přetavil kolárovsky romantické pojetí a Zacconiho naturalistické divadelnictví s propracovanými psychologickými detaily do svébytně věrného ztvárnění postavy založeného na důsledném studiu role a prožití dramatického textu (Misterova, 2013: 35-36).

${ }^{2}$ Dne 28. června 1914 byla v divadle Na Zámečku inscenována opereta Polská krev pod taktovkou samého Oskara Nedbala. Po zprávě o sarajevském atentátu byla inscenace na počátku třetího jednání zastavena. Zákaz divadelních produkcí a zábavních podniků přetrval ještě v následujících dvou dnech (Kriz, 1927: 153). 
54) Divácký zájem o představení a výkonnost činoherního souboru v sezóně 1917/1918 dokládá rekordní počet 389 představení, z nichž 186 bylo věnováno činohře. Zvýšený zájem o divadlo přetrval také v následující sezóně 1918/1919, v níž se uskutečnilo 384 představení, z nichž však pouze 37 tvořila činohra.

Divadlo se stalo kulturní platformou a současně nástrojem vyjadřování v době poznamenané suspenzí (nejen) tiskové svobody. V prvních týdnech války byla zavedena předběžná cenzura a řada listů byla zastavena. Jak připomíná Milena Berankova (1981: 222), striktní tisková praxe vedla většinu periodik k apriorní eliminaci nežádoucího obsahu, který mohl upoutat pozornost cenzorů. Redakcím byly dodávány instrukce o obsahové (ne)adekvátnosti a současně také loajální články, které měly být uveřejňovány jako redakční. Cenzuře podléhal nejen obsah listů, ale také jejich grafická úprava. Určitý prostor k vyjádření skýtaly přehledy zpráv o událostech v jednotlivých týdnech války, fejetony, nedělní př́lohy listů, články věnované zásobování atd. Není bez zajímavosti, že právě v blízkosti těchto žurnalistických útvarů byly uveřejňovány divadelní recenze.

Regionální kulturní zpravodajství zajišt'ovala především periodika Český deník a Nová doba. Státoprávně pokrokový Český deník, který vznikl fúzí Plzeňského Obzoru a Nových plzeňských listů v letech 1911 - 1912, seznamoval čtenáře s děním na poli kultury prostřednictvím rubriky Divadlo a umění. List Nová doba ${ }^{1}$, deník Československé sociálně demokratické strany, informoval o kulturních událostech rovněž v pravidelném sloupku Divadlo a umění.

Cílem této studie je prokázat, jaký prostor zaujímalo anglické a americké drama v celkové skladbě činoherního repertoáru Městského divadla v Plzni v době první světové války a vysledovat recepci jednotlivých nastudování v dobovém periodickém tisku. ${ }^{2}$

\section{Recepce angloamerického repertoáru v dobovém tisku}

První anglickou hrou uvedenou v době první světové války byla inscenace Thomasovy komedie Charleyova teta (Charley's Aunt). Premiéra se uskutečnila dne 6. října 1914 v Kühnelově překladu pod režijním vedením Jaroslava Počepického. Podle stručné dobové kritiky otištěné v periodiku Nová doba si nastudování rozverné komedie s množstvím situační komiky a kolotočem záměn a převleků zachovalo míru a vkus (A.V.A., 1914a: 4). V titulní roli studenta Babse převlečeného za tetu $\mathrm{Z}$ Brazílie podal Karel Hostaš ukázněný výkon.

Vyjma kusého hodnocení uměleckého pojetí inscenace zaznívá z recenze především kritika výběru repertoáru, inspirovaného pražským Národním divadlem. Podle recenzentovy ironické glosy vydala se česká divadla v době počínajícího válečného konfliktu duální cestou odlehčeného komediálního a exaltovaně vlasteneckého, př́padně válečného repertoáru, aniž vzala v úvahu umělecké požadavky publika i odborné veřejnosti:

„Domnívalo se [Národní divadlo] patrnè, jako ředitelství jiných divadel, že dnes neni v publiku hlubšího zájmu o výlučně umělecká dila, že lze s [sic] jeviště snésti jen bud' veselou taškařici, která dá na okamžik zapomenouti na tíhu dnešnich dní, anebo vlastenecky vzněcujici, př́padně válečnou hru, která

${ }^{1}$ List Nová doba se z původního týdeníku (1900 - 1907) transformoval v obdeník. Od 7. srpna 1914 vycházel jako deník.

${ }^{2}$ Studie vznikla s podporou grantu GA406-13-14048S Angloamerická dramatická tvorba v českých divadlech v době první světové války. 
nějak souvisí - třeba sebe chatrněji $-s$ dnešními událostmi. Zkušenosti poučily Národni divadlo, že ti, kteři doma zůstali, maji $i$ dnes touhu po uměleckých požitcích, touhu, za niž neni třeba se hanbit, nebot' proč bychom $i$ dnes nemohli sáhnout po knize, proč bychom nemohli jít do divadla, třeba že $v$ dáli bojuji naši bratři boj na život a na smrt. Učiníme-li pro naše trpicí, co bylo v našich silách, máme právo potěšit se prostředky, které nás jindy těšily a kterými jiným neškodíme. "(A.V.A., 1914a: 4)

Třebaže lze jen obtížně posoudit, do jaké míry byl text recenze poznamenán cenzurními zásahy, či víceméně oficiálními instrukcemi ohledně doporučené orientace programové skladby, přináší v podstatě realistický pohled na charakter činoherního repertoáru plzeňského divadla v první válečné sezóně. Jevišti v této době skutečně dominovaly především komedie a operety, bylo však uváděno také hodnotné české a světové drama. Pokud jde o angloamerické, respektive anglické drama, kritikem proklamované umělecké nároky veřejnosti byly pravděpodobně saturovány uváděním shakespearovských premiér.

Dne 23. ř́jna 1914 se uskutečnila premiéra Shakespearova Kupce benátského (The Merchant of Venice). Inscenaci v Sládkově překladu režíroval Jaroslav Počepický, který zároveň ztvárnil postavu žida Shylocka. Podle dobové recenze Českého denniku [sic] Počepického Shylock nevycházel z originální režijní a herecké koncepce, nýbrž připomínal v mnohém Shylocka Šmahova a Vojanova (S-y, 1914: 5). Zásadní inovaci pohledu na střet Shylocka a Antonia a současně také židovského a křest’anského světa nepřinesla ani scénická výprava.

Slabina inscenace spočívala podle recenze v nevhodném obsazení mužských rolí. Kritik uvedl, že Richard Branald, Zdeněk Knittl a Karel Beníško vystoupili v úlohách (nespecifikováno, v jakých), jež jim absolutně nenáležely. Rovněž ztvárnění Bassania Bedřichem Karenem vyznělo podle téhož zdroje prŕíliš jednotvárně a v celkovém pohledu postrádalo uhlazenost a zdvořilost. V představení naopak excelovala Otýlie Beníšková jako Porcie. V (nadneseném a obdivném) př́měru kritika splývaly Shakespearovy verše z jejích rtů jako kř̌ištálové perly. Zdařilého provedení se dostalo také dalším ženským postavám, Nerrise (Marie Bečvářová) a Jessice (Antonie Fišerová), což naznačuje uměleckou převahu dámské části souboru. Rušivě působila podle kritiky hudební vložka, nedůslednost kostýmů (např. padající čepice Richarda Branalda a Karla Beníška) a neuspokojivá interpretace Shakespearových veršů.

Zmíněné nedostatky pravděpodobně neubraly představení na atraktivnosti, o čemž dle recenze svědčí jeho vysoká návštěvnost.

V závěru roku 1914 byla uvedena Shawova dobrodružná veselohra z přelomu století Kapitán Brassbound (Captain Brassbound's Conversion) v režii Josefa Fišera a překladu Karla Muška. Podle dobové kritiky napomohla válečná atmosféra lepšímu porozumění exotickému koloritu hry a dodala dramatu na aktuálnosti:

„Ba vlastně dnes, kdy ve vzdálených krajich z náhodného pohybu umístěni lodí, [sic] vznikaji mezinárodni zápletky, $k d y$ do všeevropské války posiláno je barevné vojsko z kolonií, rozumíme lépe jejímu cizokrajnému koloritu. Třeba nejsme státem s koloniemi, všimáme si ted' těchto otázek. “(A.V.A., 1914b: 4)

Režisér učinil středobodem inscenace ženu. Lady Waynfletová v podání Otýlie Beníškové byla činorodá a zároveň zdravě reformní, nesobecká, laskavá i 
spravedlivá. S úsměvem a veselou myslí, bez zbytečného moralizování, dokázala zakročit v pravý čas a změnit své bližní $\mathrm{k}$ lepšímu.

Celkově se inscenace setkala s př́znivým ohlasem kritiky, byt' v hodnocení zazněla i drobná invektiva:

„Ze způsobu, kterým naši herci hru hraji, je sice patrno, že politika, právo, jim tuze $k$ srdcím nepřirostly. Nedovedou o nich mluvit s náležitým vnitřním ohněm. Ale jinak se hrálo velmi pěkně. “ (A.V.A., 1914b: 4)

Utlumení politické rétoriky $\mathrm{v}$ době narůstajícího válečného konfliktu mohlo být naopak režijním záměrem. Vágní tón politických proklamací a celkově ambivalentní postoj $\mathrm{k}$ politickému diskurzu mohl být sdělením divákovi, sdílenou nechutí či implicitním odsouzením válečného dění (viz dále).

Rok 1915 přinesl významnou shakespearovskou premiéru. Dne 5. dubna 1915 byla v Plzni poprvé uvedena Boure (The Tempest). Inscenaci nastudoval Karel Veverka, který se zasloužil o první uvedení Sládkova překladu na českém jevišti, za doprovodu scénické hudby Antona Beer-Waldbrunna pod taktovkou vynikajícího Václava Talicha. Základ Veverkovy režijně-scénické koncepce představovalo využití shakespearovského jeviště. Jevištní pole bylo dvoučlenné, tvořené proscéniem a vyvýšeným zadním jevištěm. V celkovém pohledu však moderně řešená předscéna př́liš kontrastovala $\mathrm{s}$ klasickým arkádovitým pozadím, kde se odehrávala většina výstupů. Přes určitou disharmonii celkového jevištního prostoru se Veverkovi podařilo dosáhnout výrazného efektu jednoduchými dekoracemi a působivým osvětlením.

Jednotlivé výkony se setkaly převážně s pozitivní odezvou. Jaroslav Vojta dokreslil Kalibána „drastickou maskou“, vhodně modulovaným hlasem a akrobatickými výkony. Antonie Fišerová vystihla éterickou podstatu Ariela odpovídajícími gesty, lehkostí chůze a graciézností poskoků. Otýlie Beníšková a Bedřich Karen přiblížili postavy Mirandy a Ferdinanda pohádkovým bytostem. Karel Hostaš a Jaroslav Pulda vytvořili ve Stefanovi a Trinkulovi věrohodné shakespearovské charaktery oplývající humorem. Vedralův Prospero byl však neustálým jednostranným zdůrazňováním dobroty ochuzen o atribut tajemnosti a vznešenosti. Kritik nesmlčel obecnou výtku vůči řečovému projevu, který ve většině případů postrádal potřebnou plasticitu a blížil se spíše recitaci než mluvě v inscenaci dramatu (S-y, 1915a: 6). Třebaže recenze explicitně nezmiňuje exotický kolorit hry, jako tomu bylo např. v nastudování Kapitána Brassbounda, lze se domnívat, že publikum mohlo sympatizovat s Kalibánovou touhou po svobodě, jíž byl zbaven Prosperem.

Celkově zdařilému vyznění inscenace napomohly realistické efekty větru a bouře a zejména hudba, která dokonale souzněla s děním na jevišti. Přes určité drobné nedostatky vzbudila Bouře poměrně značný zájem veřejnosti, nebot' šlo o první (a bohužel zároveň poslední) nastudování na plzeňském jevišti vůbec. ${ }^{1}$ Výtěžek představení byl věnován osleplým a zmrzačeným vojínům (S-y, 1915a: 6).

Shakespeare dominoval jevišti také ve druhé polovině roku 1915. Dne 21. listopadu byla uvedena premiéra Komedie omylu (Comedy of Errors) v překladu

${ }^{1}$ V Národním divadle byla hra uvedena až v roce 1937 v překladu Otokara Fischera. V Plzni již nastudována nebyla. 
Josefa Václava Sládka a režii Josefa Fišera. Podle recenze otištěné v Českém denníku [sic] se Fišer inspiroval Kvapilovou inscenací uvedenou v Národním divadle (S-y, 1915b: 6). Kusé informace o plzeňském nastudování se omezují na konstatování, že provedení bylo uspokojující. Celkový umělecký dojem pravděpodobně podpořilo vhodné herecké obsazení rolí blíženců Antifolů (Bedřich Karen a Jan Martin si byli k nerozeznání podobni) a Dromiů (Ladislav Fišer a Karel Hostaš). Vrcholem představení byla herecká kreace Otýlie Beníškové v roli žárlivé manželky efezského Antifola.

V těsném sledu za Shakespearovou Komedií omyli̊, tj. 24. listopadu 1915, byla uvedena Maughamova konverzační komedie Lady Frederick v Guthově překladu a režii Jaroslava Počepického. Dobová kritika se zaměřila především na obsah Maughamovy hry oscilující kolem postavy eponymní hrdinky, přitažlivé, energické a šlechetné ženy zralého věku, a jejích ctitelů (A.V.A., 1915: 6). Jednomu z nich, oddanému mladému obdivovateli, lordu Merestonovi, otvírá $\mathrm{v}$ závěru láskou zaslepené oči zdůrazněním vzájemné věkové nerovnosti. Přesto není odsouzena $\mathrm{k}$ osamělosti. Finanční i společenskou oporu nalézá v bohatém gentlemanovi Paradinu Fouldesovi. Podle citované recenze vyznělo však št'astné zakončení konvenčně a uměle (mohli bychom hovořit i o jisté ironii), nebot' Jaroslav Počepický od počátku stylizoval Fouldese do polohy zhýralce a šosáka. Výsledný efekt volby lady Frederickové ztratil $\mathrm{v}$ tomto kontextu svoji pointu a nabyl spíše ironického (či provokativního) zabarvení (kdo dlouho vybírá, přebere), třebaže nelze vyloučit, že právě ironický či karikaturní podkres byl režijním záměrem. Dochované ohlasy inscenace bohužel neumožňují více než hypotézy.

V únoru 1916 uvedl Josef Fišer premiéru Shawovy hry Androklus a lev (Androcles and the Lion) v překladu Karla Muška. Pohádková komedie založená na prríběhu o přátelství mezi otrokem a lvem se na repertoáru zřejmě neocitla náhodou. Nadčasové téma lidské víry a střetu mezi křest’any a Caesarovými stoupenci bylo $\mathrm{v}$ době válečného konfliktu dobře čitelné.

„,Ve hře spočivá myšlenka: Učinilo křestanství člověka jiným, stal se lepším, a zda-li křstanství zahladilo v nèm stopy prirozenosti a individuálních vlastností? - A jaký zájem měli panujici Caesarové? Jim byla lhostejna vira lidi, jim jednalo se pouze o to, aby ukojili potíráním jinověrcủ své okoli a rozhodujici špice. Vèc viry je jim pouhou formalitou, věc vlády a ovládáni jest jim vším. Tak ku př. [sic]: Když někdejši přisný křestan, silák Ferrovius, který hlásal neodpírati zlu, v obraně života v aréně (tam se v něm probudila lidská přirozenost) zabiji šest svých pohanských soupeřu, pravi krvežiznivý Caesar: 'Pronásledování krest’anů musí přestati. Dovedou-li se křestané rvát jako tu ten zde, chci, aby jen krest'ané pro mé bojovali.',' (Anonymni, 1916a: 3)

Narážku na zájem panujicich Caesarů a jejich lhostejnost vůči víre lidí vnímalo obecenstvo $\mathrm{v}$ kontextu zhoršujících se hospodářských poměrů a výpadků $\mathrm{v}$ zásobování, provázených stávkami za zvýšení mezd a hladovými demonstracemi, pravděpodobně velmi intenzivně. Inscenace však byla výrazně poznamenána cenzurními zásahy, jež oslabily satirický náboj hry a současně daly vznik divadelní anekdotě:

A: Těžko řici, která úloha ve hře je nejvděčnější.

$B$ : Myslim, že role lva.

A: Ale kdež. Vždyt' jest to pouze výkon mimický.

B: Právě proto: nebot' byla nejvýmluvnější, poněvadž nemohlo v ni býti škrtáno. (Anonymni, 1916a: 4) 
Kritik Českého deníku (S-y, 1916: 6) užil v souvislosti s cenzurními škrty relativně jemnějšího metaforického přirovnání k ocelovým nůžkám nutnosti.

Ferrovia ztvárnil nový člen činoherního souboru Emanuel Rabas jako skutečného siláka, vnímavého a zároveň hněvivého křest’ana svádějícího boj $\mathrm{s}$ náboženskými př́kazy i se sebou samým. Jeho působivý umělecký výkon odměnilo obecenstvo potleskem na otevřené scéně. V Androklovi Jaroslava Hostaše se svářil ryze dobrý člověk s komickou postavou, aniž komická stránka převážila jeho dobrý charakter. Vypočítavému chytráku Spinthovi dodal Rudolf Riegel prŕliš tragický nádech. V Lavinii vytvořila Otýlie Beníšková ženu filozofující, ironizující a koketující, jež se z mučednické cesty vydala zpět do víru života. Spíše než obyvatelku antického Ríma připomínala inteligentní moderní ženu. Caesar Jaroslava Počepického postrádal svrchovanost a krvežíznivost, takže jeho závěrečný obrat vyzněl příliš neurčitě.

Věrohodného a umělecky působivého lva vytvořil baletní mistr Jaroslav Hladík prostřednictvím široké škály neverbálních a mimických prostředků, např̀. mocným řevem, vrčením, skoky i přívětivým lísáním. ${ }^{1}$

Přes výrazné cenzurní škrty si hra podržela satirický ráz a vyvolala př́znivou odezvu kritiky i publika.

V roce 1916 uplynulo tři sta let od Shakespearova úmrtí. V Praze bylo na počest světového dramatika uvedeno patnáct inscenací Shakespearových her, tzv. Shakespearovský cyklus, $\mathrm{v}$ Kvapilově režii. Plzeň se $\mathrm{k}$ oslavám přidala třemi shakespearovskými inscenacemi. Dne 4. května 1916 proběhla premiéra Hamleta (The Tragedy of Hamlet, Prince of Denmark), 5. května byla provedena tragédie Romeo a Julie (Romeo and Juliet) a 14. května byl inscenován Sen noci svatojanské (A Midsummer Night's Dream).

Největšího ohlasu dosáhlo představení Hamleta v překladu Josefa Václava Sládka a režii Jaroslava Počepického. Premiéra byla očekávána s napětím, nebot' plzeňské publikum mělo ještě v paměti Budilovo nastudování s Milošem Novým v hlavní úloze. V květnové premiéře se v roli Hamleta úspěšně představil přední člen plzeňského činoherního souboru Bedřich Karen, který vytvořil melancholického prince podléhajícího citu a náladám. Jeho silnou emotivní slupkou však neustále prostupovala racionalita. I ve vzplanutích citu neztrácel praktické smýšlení. Neustále uvažoval o všem, co viděl, slyšel a cítil. Avšak prŕlišné rozumování jej vysilovalo psychicky i fyzicky. Jeho tvář byla chorobně bledá smutkem a duševními útrapami, oči a líce měl vpadlé, tělo zesláblé. Činorodosti a rozhodnosti nabýval pouze ve chvílích vzrušení a citového vzplanutí, aby se v momentu opět uzavřel do sebe a žil více ve svém vnitřním než skutečném světě. Stav Hamletova zmučeného nitra se odrážel v jeho váhavých gestech, nerozhodné chưzi a přerývaných větách, z nichž prokmitávalo zděšení a rozhořčení. Klíčem k Hamletově rozbolavělé mysli se stal monolog „Být, či nebýt“. V souvislosti s koncepcí postavy Hamleta i jeho promluv lze se domnívat, že Hamletův vnitřní konflikt a kontemplace mohly být transponovány do obecnější sféry úvah o autonomii českého národa (Bures, 1916: 4)

${ }^{1} \mathrm{~V}$ souvislosti s výstupy lva přinesla recenze listu Nová doba kritickou a z dnešního hlediska úsměvnou výtku vưči scénické výpravě v prvním jednání: „Výprava měla četné vady, v prvním jednání mělo být hráno v džunglích, ale hrálo se v nějaké zahradě, kam lvi nechodí.“ (Anonymni, 1916a: 3). 
Vyjma detailního zhodnocení umělecké koncepce postavy Hamleta přinesla recenze také celistvý pohled na pojetí jednotlivých postav. Horatio Karla Želenského zůstal až do poslední chvíle Hamletovým neochvějným prrítelem. Otýlie Beníšková zdůraznila Ofeliinu pokornou lásku, oddanou poslušnost i šílenství pramenící $\mathrm{z}$ neopětovaného milostného citu. Fišerův Polonius podle dobové kritiky poněkud postrádal vřelejší otcovský tón $\mathrm{v}$ promluvách $\mathrm{k}$ temperamentnímu a někdy př́liš ukvapenému Laertovi (Vladimír Jerman). Jaroslav Počepický obrousil hrany Claudiovy zločinnosti a dodal postavě lidský rozměr. Adolf Kreuzmann proměnil ducha Hamletova otce v majestátní, záhrobní zjevení.

Autorem scénické výpravy byl Bohumil Krs (1890 - 1962), malír, grafik, ilustrátor a scénograf, absolvent pražské umělecko-průmyslové školy. Krsova maximálně zjednodušená scéna, tvořená dvěma oblouky spojenými postranními stěnami $\mathrm{s}$ dveřmi, napomáhala rychlému a efektivnímu stř́dání obrazů. $\mathrm{S}$ jednoduchým scénickým uspořádáním souzněla kostýmní výprava, zhotovená rovněž podle Krsových návrhů. Atmosféru inscenace příhodně dokreslovalo barevné, žluté a červené osvětlení.

V krátkém časovém sledu po uvedení Hamleta uskutečnila se premiéra Shakespearovy komedie Sen noci svatojanské. Hru nastudoval Jaroslav Počepický v překladu J. V. Sládka s hudbou Felixe Mendelssohna Bartholdyho.

Režisér vyzdvihl především pohádkový charakter hry, který podtrhovala zdařilá scénická výprava, zejména pohádkový les ve druhém jednání, který „,pưsobil hluboko na duši divákovu, jejž přiměl věřiti $\mathrm{v}$ možnost všech těch divů nezemských,“a obsazení jednotlivých úloh (Vondruska, 1916: 5). Thesea a Hypolitu ztvárnili Emanuel Rabas a Marie Procházková s uměřeným smyslem pro povýšenost, kterou zjemňovala vyvážená kombinace radosti a štěstí athénského páru (jb, 1916: 6). Lysander Vladimíra Jermana byl vytrvalý v lásce a rozvážný v mluvě i gestech. Hermie Růženy Cellarové byla něžná i hravá, avšak v momentech rozepře obdobně hašteřivá jako Helena Anny Machové. Demetrius Drahoše Želenského představoval podle citované kritiky př́liš energického a temperamentního milovníka. Oberona ztělesnila Antonie Košnerová jako rozvážného a dobromyslného vládce. Titanie v podání Otýlie Beníškové připomínala podle citované recenze „sladký zjev jiných světů“. Puck Antonie Fišerové blížil se (zejména kostýmem) postavě fauna.

Inscenace promlouvala $\mathrm{k}$ soudobému divákovi především prostřednictvím pohádkových prvků a poetického zabarvení. Kombinace magické atmosféry athénského lesa a drsně poetického světa řemeslníků přinášela dočasné zapomnění na válečné strasti a $\mathrm{v}$ intencích pohádkového rámce také víru $\mathrm{v}$ dobrý konec. Úspěchu inscenace, označené kritikou za jeden z nejzdařilejších uměleckých počinů sezóny, napomohla kostýmní a scénická výprava, podtrhující pohádkový charakter prostředí i spontánnost hereckého projevu.

Dne 17. května 1916 propůjčilo plzeňské Městské divadlo jeviště prostějovskému divadelnímu Spolku Tyl, který symbolicky uzavřel shakespearovský cyklus inscenací Zkroceni zlé ženy, v níž pohostinsky vystoupil Eduard Vojan (Anonymni, 1916c: 6).

V listopadu 1916 uvedla činohra komedii Jamese Matthewa Barrieho Chlapík Crichton (The Admirable Crichton) v režii Jaroslava Počepického. Režisér zaměřil pozornost na hlavní postavu hry, komorníka Crichtona, a jeho proměnu z hraběcího sluhy na faktického vůdce skupiny aristokratů ztroskotaných na opuštěném tropickém ostrově. Crichton Otto Čermáka byl zdatným mužem, který dokázal obratně využít svých fyzických, intelektuálních a komunikačních schopností ve vskutku darwinovském boji o život. Svoji de facto vnucenou roli vůdce zaujal stejně 
pružně a nenásilně jako po zachránění své původní místo. Jaroslav Počepický odhalil dvojí tváře hraběte Loama. Vážnou a arogantní v civilizované společnosti a poníženou a komickou uprostřed tropické divočiny. Úlohu hraběcí dcery Mary, zamilované do Crichtona, pohostinsky ztvárnila Marie Vildová. Dobrosrdečnou komornou představovala Marie Bečvářová.

Komedie o výměně společenských rolí a (ne)rovnosti mezi společenskými tř́idami, utilitárně proklamované lordem Loamem a přijímané rozpačitě aristokraty $\mathrm{i}$ samým personálem, vzbudila u diváků značný ohlas (i, 1916: 3-4).

Pozoruhodným uměleckým počinem roku 1917 bylo uvedení Shawovy hry Caesar a Kleopatra (Caesar and Cleopatra) v režii Jaroslava Počepického a překladu Karla Muška dne 19. dubna 1917, již za měsíc po premiéře (10. března) v Městském divadle na Královských Vinohradech.

Režijní koncepce položila důraz především na vztah Caesara a Kleopatry a povahokresbu obou postav. Jaroslav Počepický ztvárnil Caesara jako mnohovrstevnou postavu. Byl psychologem, ironikem a hlasatelem morálky i lásky k bližnímu. Caesarovým výchovným působením a zejména láskou se mladičká egyptská královna postupně proměňovala $\mathrm{z}$ rozmazleného a hravého kotěte ve vládkyni a $\mathrm{z}$ dítěte $\mathrm{v}$ ženu. Interpretka (herečka Krejsová) vystihla mnohostrannost Kleopatřina charakteru, její smyslnost, dětskou rozmazlenost i barbarskou krvežíznivost.

List Nová Doba přinesl podnětnou poznámku o obtížné uchopitelnosti inscenace pro publikum:

„Na jisté části obecenstva byla pozorována nedostatečná informovanost o dile, jeho myšlence a smyslu - doporučovalo by se, aby divadlo při takovýchto premiérách vydalo informačni studii, jež by usnadnila proniknuti tak obsáhlého a dosti těžkého dila. " (Anonymni, 1917: 3)

Restaurační drama z pera Thomase Otwaye - Zachránění Benátek (Venice Preserved) - zvolil pro své nastudování Josef Fišer v českém převodu V. A. Junga. Premiéra se uskutečnila dne 11. dubna 1918. Hru, zaznívající narážkami na jakubovské společensko-politické události a osobnosti, zasadila režie do klasického rámce (X, 1918: 5). Děj osciloval kolem lásky, cti a přátelství na pozadí jemného přediva ctižádosti a podlosti. V popředí inscenace se ocitla Belvidera, v podání Otýlie Beníškové př́iznačně ženská a citlivá. Jaffier Otto Čermáka neustále kolísal mezi láskou $\mathrm{k}$ manželce a slibem daným prŕteli Pierrovi (Emanuel Rabas). Jaffierova nerozhodnost a slabost charakteru výstižně kontrastovala s Pierrovou pevnou a důslednou povahou. Antoniovu zkaženost věrohodně vyjádřil Josef Fišer. Belvideřina otce, pyšného senátora Priula, představoval František Kreuzmann.

Fišerovo nastudování restauračního dramatu zprostředkovalo barvitý pohled na politickou konspiraci, motivovanou různými politickými i ryze osobními důvody. Téma hry, plejáda typických ničemů a završení dějové spleti vpravdě tragickým koncem, v němž nalezli smrt Pierre, Jaffier i Belvidera, přiřadily inscenaci k divácky atraktivním nastudováním.

V souvislosti s divadelní scénou je třeba zmínit také Loutkové divadlo feriálních osad ${ }^{1}$, jehož členem se v roce 1917 stal všestranný umělec, výtvarník, režisér, dramaturg a loutkoherec Josef Skupa. Loutková divadelní představení byla určena nejen dětem, ale prostřednictvím protiválečných scének také dospělým. Dne

${ }^{1}$ Feriální osady byly obdobou prázdninových táborů pro děti z chudých poměrů. Loutkové divadlo feriální osady podporovalo a pořádalo pro ně představení. 
23. záŕí 1918 uvedlo Loutkové divadlo poprvé satirickou scénu, v níž Kašpárek symbolicky pohřbívá monarchii. Performance vzbudila u diváků bouřlivou odezvu. Vzhledem kblížícímu se konci války zůstala otevřená proklamace antimonarchistických postojů bez odezvy, přestože perzekuce (nejen) kulturní sféry byla $\mathrm{v}$ podstatě organickou součástí vládní politiky. Vzhledem $\mathrm{k}$ blížícímu se konci války úřady na otevřenou proklamaci antirakouského postoje nereagovaly.

\section{Závěr}

V době první světové války tvořilo činoherní repertoár především klasické národní drama (Klicpera, Tyl, Jirásek, Vrchlický, Mahen), skýtající dostatek prostoru k ústrojné aktualizaci, a klasické drama světové, tj. německé, norské a ruské (Schiller, Ibsen, Krylov, Mjasnický, Dostojevský aj.). Anglické drama, inscenované převážně ve Sládkových a Muškových překladech, představovalo kvalitativně významnou, byt' kvantitativně spiše marginalizovanou část programové skladby. Třebaže ráz činoherního repertoáru určovala především Společnost českého divadla v Plzni, dočasná konjunktura divadla projevující se postupně od roku 1916 umožnila rovněž nastudování méně hodnotných prací.

Anglickému repertoáru dominovala (nejen početně, ale především uměleckou úrovní) shakespearovská a shawovská nastudování. Z plejády shakespearovských produkcí připomeňme především památnou inscenaci Hamleta (1916), jejíž uvedení pravděpodobně rezonovalo se silným antirakouským nábojem Kvapilova shakespearovského cyklu inscenovaného téhož roku v Praze. V Hamletovi spojil Miloš Nový intenzivní emocionální prožitek s pragmatickým uvažováním a přetavil jej v melancholika, vyznačujícího se zjitřenou vnímavostí i schopností racionální úvahy. Nastudování Kupce benátského (1914), Komedie omylů (1915) a Snu noci svatojanské (1916) těžila především z kvalitního uměleckého výkonu Otýlie Beníškové (Porcie, manželka efezského Antifola a Titanie). V roce 1915 se svého jediného plzeňského uvedení dočkala Bouře (1915), inscenovaná - poprvé na českém jevišti - v Sládkově překladu. Celkově se inscenace Shakespearových a Shawových her vyznačovaly kultivovanou režijně-dramaturgickou koncepcí ${ }^{1}$ a detailní povahokresbou ústředních protagonistů na pozadí emocionálně vypjatých situací, osobních i historických střetů a milostných vztahů a výraznými hereckými výkony (Otýlie Beníšková, Bedřich Karen).

Dobové recenze, zveřejněné v listech Český deník a Nová doba, přnášejí v podstatě komplexní umělecký obraz jevištních nastudování s důrazem na výkony jednotlivých protagonistů, scénografii a kostýmní návrhy. Aluze na společenskopolitickou realitu se vzhledem k cenzurní supervizi vyskytují pouze sporadicky, zahalené hávem teatrologického či literárně-teoretického výkladu dramatického díla, jako tomu bylo u Androkla a lva (1916), jehož nastudování přes rigidní cenzurní zásahy oslovilo diváky svým nadčasovým tématem. Konkrétní zmínka o válečném dění, tj. o mezinárodních zápletkách, barevném vojsku z kolonií a všeevropské válce se objevuje pouze v recenzi nastudování Kapitána Brassbounda (17. listopadu 1914). Byt' konfrontace válečné a divadelní reality zde (údajně) slouží jako východisko odhalování a pochopení exotického koloritu hry, mohlo jít o narážku na mobilizaci, či o potlačení prorakouské rétoriky, jíž se vyznačovaly např. tehdejší Národní listy. Nesouhlasný postoj hereckých představitelů jednotlivých postav k politickému

${ }^{1}$ Největší zásluhu si v tomto ohledu připsal Jaroslav Počepický. Ke zdařilým dobovým nastudováním je však třeba přičíst i režijní počiny Josefa Fišera a Veverkovo nastudování Bouře, vyznačující se souhrou mezi činoherním projevem a hudební složkou. 
diskurzu hry (a hypoteticky také k soudobému dění), doložený poznámkou o jejich nedostatečném entuziasmu pro právo a politiku, v podstatě potvrzuje odmítavý postoj Plzeňanů vůči válečnému konfliktu. $Z$ tematického hlediska lze určitou rezonanci s válečnými událostmi vysledovat v inscenaci Chlapika Crichtona (1916), spojující komediální odlehčení se sociálním podtextem. Přítomnost jinotajného sdělení lze z dnešního hlediska prokázat jen obtížně, avšak s ohledem na diváckou oblibu i rok uvedení je nelze vyloučit. Politické narážky mohly být rovněž vkomponovány do inscenace Zachráněni Benátek (1918), třebaže konkrétní důkazy bohužel neexistují.

V době válečné skýtalo (nejen) plzeňské divadlo možnost dočasného úniku z tíživé politické a hospodářské reality, posilovalo svoji národně buditelskou funkci a stávalo se oporou na cestě za národní i státní svébytností.

\section{References}

ANONYMNI. 1916a. Sloupek Divadlo a umeni. Androklus [sic] a lev (1. cast). In: Nova doba, roc. XXI, c. 49, s. 3-4. ISSN 1804-3852

ANONYMNI. 1916b. Sloupek Divadlo a umeni. Androklus [sic] a lev (2. cast). In: Nova doba, roc. XXI, c. 50, s. 3. ISSN 1804-3852

ANONYMNI. 1916c. Z kancelare mestského divadla v Plzni [Zkroceni zle zeny]. In: Cesky denik, roc. (V) 52, c. 135, s. 6.

ANONYMNI. 1917. Caesar a Kleopatra. In: Nova doba, roc. XXIII, č. 93, s. 3. ISSN 1804-3852

A.V.A. 1914a. Sloupek Divadlo. Thomas Brandonova Charleyova teta. In: Nova doba, roc. XIX, c. 148 , s. 4. ISSN 1804-3852

A.V.A. 1914b. Sloupek Divadlo. Kapitan Brassbound. In: Nova doba, roc. XIX, c. 183, s. 4. ISSN 1804-3852

A.V.A. 1915. Divadlo. Lady Frederick. In: Nova doba, roc. XX, c. 282, s. 6. ISSN 1804-3852

BERANKOVA, M. 1981. Dejiny zurnalistiky. I. dil. Cesky periodicky tisk do roku 1918. Praha: Nakladatelstvi novinar.

BURES, J. 1916. Rubrika Divadlo a umeni. Hamlet. In: Cesky denik, roc. (V) 52, č. 125, s. 4. 1801-2620. ISSN neuvedeno

CEPELAK, V. a kol. 1967. Dejiny Plzne. II. dil. Od roku 1788 do roku 1918. Plzen: Západoceske nakladatelstvi v Plzni.

I. 1916. Divadlo - umeni. Chlapík Crichton. In: Nova doba, roc. XXI, c. 272, s. 3-4. ISSN 1804-3852

JB. 1916. Divadlo a umeni. Sen noci svatojanske. In: Cesky denik, roc. (V)52, č. 135, S. 6.

KRIZ, F. 1927. Divadlo mesta Plzne v letech 1902 - 1927. Jubilejni spisek. Plzen: Nakladem mesta Plzne.

MARTINOVSKY, I. a kol. 2004. Dejiny Plzne v datech. Plzen: Archiv mesta Plzen, nakladatelstvi Lidove noviny. ISBN 80-7106-723-7

MISTEROVA, I. 2013. Angloamerické drama na plzenskych scenach. Plzen: Vydavatelstvi ZCU v Plzni, 2013. ISBN 978-80-261-0193-2

MISTEROVA, I. 2010. O Romeo, Romeo! wherefore art thou Romeo? Four Major Romeo and Juliet Productions on Pilsen Stages. In: Silesian Studies in English. Opava: Slezska univerzita v Opave, s. 353-370. ISBN 978-80-7248-622-9

MISTEROVA, I. 2010.Translation and Performance: the Presentation of Shakespeare in Pilsen in the Context of Social and Political Events in the 20th and 21st Centuries. In: Brno Studies in English. Brno: Masaryk University, s. 175-189. ISSN 0524-6881 PROCHAZKA, J. 1965. Sto let ceskeho divadla v Plzni. Plzen: Západoceske nakladatelství v Plzni ve spolupraci s Divadelnim ustavem v Praze. 
S-Y. 1914. Rubrika Divadlo a umeni. Kupec benatsky. In: Ceský dennik [sic], roc. 50, c. 283, s. 5. ISSN 1801-2620

S-Y. 1915a. Rubrika Divadlo a umeni. Boure. In: Ceský dennik [sic], roc. (IV) 51, c. 96, s. 6. ISSN 1801-2620

S-Y. 1915b. Rubrika Divadlo a umeni. Komedie plna omylu. In: Ceský dennik [sic], roc. (IV) 51, c. 236, s. 6. ISSN 1801-2620

S-Y. 1916. Divadlo a umeni. Z plzenskeho divadla. Androkles a lev. In: Ceský dennik [sic], roc. 5 , c. 8 , s. 6 .

VONDRUSKA, F. A. 1916. Divadlo a umeni. K zitrejsi premiere v mestskem divadle v Plzni. Sen noci svatojanske. In: Ceský dennik, roc. (V) 52, c. 132, s. 5. ISSN 18012620

X. 1918. Divadlo a umeni. Z plzenskeho divadla. [Zachraneni Benatek]. In: Ceský dennik, roc. 7, c. 90 , s. 5 .

Words: 5761

Characters: 41633 (23,13 standard pages)

PhDr. Ivona Misterova, Ph.D.

Department of English Language and Literature

Faculty of Philosophy and Arts

University of West Bohemia in Pilsen

Sedláčkova 15

30614 Plzen̆

Czech Republic

yvonne@kaj.zcu.cz. 